\title{
The Admissibility of Young People's Statements Under the Proposed Youth Criminal Justice ACT
}

\author{
SANJEEV ANAND ${ }^{*}$ AND JAMES ROBB ${ }^{*}$
}

This article examines the impact of Bill C-7, the Youth Criminal Justice Act, on the admissibility of young people's statements. Although the proposed reforms appear to leave admissibility within the discretion of youth court judges, the authors argue that the YCJA significantly curtails the types of factors that judges can consider when assessing the admissibility of youth statements. The three sources of law applicable to young offender statements are examined: the legislative provisions, the common law rules of voluntariness. and ss. 7. 9. and 10 of the Charter. The authors analyze s. 146 of the YCJA, the applicable section to youth statements, and compare it to the previous version of the Bill and to the current provisions of the Young Offenders Act. The case law concerning voluntariness and Charter rights are also discussed, as well as the potential interrelationship between the three sources of law. In addition, the article explores when youth statements made to a person not in authority will be inadmissible.
Cet article porte sur l'incidence du projet de loi $C$. 7. c est-à-dire la Loi sur le système de justice pénale pour les adolescents, notamment l'admissibilité des déclarations des jeunes. Bien que les réformes proposées semblent laisser l'admissibilité de cette déclaration à la discrétion des juges des tribunaux pour adolescents, les auteurs estiment que la Loi paralyse considérablement le genre de facteurs dont les juges peuvent tenir compte au moment d'en évaluer l'admissibilité. Les trois sources de droit qui s appliquent aux déclarations de jeunes délinquants sont étudièes : les dispositions législatives. les règles d'expression de la volonté de la common law et les paragraphes $\%, 9$ et 10 de la Charte. Les auteurs analysent le paragraphe $14 \dot{6}$ de la Loi, la section qui s'applique aux déclarations des jeunes et la comparent à la version précédente du projet de loi et aux dispositions actuelles de la Loi sur les jeunes contrevenants. La jurisprudence relative à l'expression de volonté et la Charte des droits y sont aussi traitées de mème que les relations éventuelles entre les trois sources de droit. En outre, l'article explore dans quelles situations des déclarations de jeunes faites à une personne qui ne se trouvent pas dans une situation d'autorité ne sont pas admissibles.

\section{TABLE OF CONTENTS}

I. INTRODUCTION . . . . . . . . . . . . . . . . 772

II. LEGISLATIVE OVERVIEW . . . . . . . . . . . . . . . . . . . . 773

A. COMPARISON SUMMARY OF KEY STATUTORY RULES . . . . . . 773

1II. DISCUSSION OF RULES OF ADMISSIBILTY . . . . . . . . . . 778

A. SOURCES OF RULES GOVERNING ADMISSIBILITY . . . . . . 778

B. VoluntARINESS . . . . . . . . . . . . . . . . 780

C. THE INTERPLAY OF VOLUNTARINESS, SECTION 56

OF THE YOA, SECTION 146 OF THE YCJA,

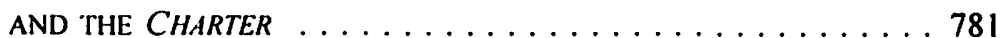

IV. INTERRELATIONSHIP OF VOLUNTARINESS AND

Statements Made to a PERSON Not in Authority . . . . . . . . . 782

V. JUDICIAL DISCRETION TO ADMIT STATEMENTS

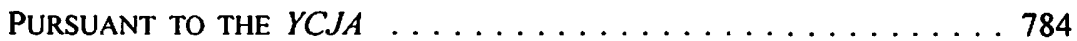

VI. CONCLUSION ...................... 786

- Assistant Professor, Faculty of Law, University of Alberta.

-. Counsel, Constitutional Law Division, Alberta Department of Justice. 


\section{INTRODUCTION}

Law enforcement officials have expressed concern about the provision in the Young Offenders $A c t^{\prime}$ that affords special protection to youths regarding the admissibility of their statements to persons in authority. During its hearings on Canada's youth justice system, the Standing Committee on Justice and Legal Affairs heard from the Canadian Association of Chiefs of Police, whose representatives warned that the demanding requirements of the current law often lead to voluntary statements made by "street smart" youths being ruled inadmissible due to minor violations of the statutory provisions. ${ }^{2}$

Yet there is also abundant evidence suggesting that young people need enhanced protection when they are being questioned by police. Current research warns that delinquent adolescents are more likely to implicate themselves (sometimes falsely) and waive their due process rights when they are given the same type of warnings and assistance as are given to adult accused, and that this tends to happen more frequently to youths younger than fourteen years old. ${ }^{3}$

An infamous example of the vulnerability of young people to police interrogation tactics is the American case of Ryan Harris. In that case, after a series of lengthy police interviews, two young boys confessed to killing eleven-year-old Harris in July 1998. Charges were dropped after detectives found semen on Harris' underwear and it was determined that both boys were too young to produce semen. ${ }^{4}$

At first blush, Canada's latest attempt at juvenile justice reform, the proposed Youth Criminal Justice Act, ${ }^{5}$ seems to leave the determination of admissibility of youth statements obtained in contravention of the statutory safeguards as a matter of largely unfettered judicial discretion. Indeed this view was espoused in academic commentary soon after the Bill was first introduced in the House of Commons. ${ }^{6}$

Both the initial version of the $Y C . J A$ and the current form of the Bill reflect, to some extent, the recommendation of the Standing Committee on Justice and Legal Affairs, which urged abandoning the $Y O A$ 's approach of automatically excluding any statement given to a person in authority when the statutory prerequisites to admission are not fully met.' Thus under the new juvenile justice legislative regime there will be some judicial discretion to admit these statements into evidence.

Young Offenders Acl, R.S.C. 1985, c. Y-1 [hereinafter YOA].

Canada, House of Commons, Thirteenth Report of the Standing Committee on Justice and Legal Affairs: Renewing Youth Justice (Ottawa: Canada Communications Group-Publishing, Public Works and Government Services Canada, 1997) at 69-72 [hereinafter Renewing Youth Justice]. See E.S. Scott \& T. Grisso, "The Evolution of Adolescence: A Developmental Perspective on Juvenile Justice Reform" (1997) 88 J. Crim. L. \& Criminology 137 at 169. D.C. Vock, "New law on kid confessions flawed: critics" Chicago Daily Law Bulletin (31 August 2000) 1.

- See S.S. Anand, "The Good, the Bad, and the Unaltered: An Analysis of Bill C-68, the Youth Criminal Justice Aci" (1999) 4 Can. Crim. L.R. 249 at 269-270.

$7 \quad$ Renewing Youth Justice, supra note 2 at 76. 
Nevertheless, since the $Y C J A$ was first introduced, a shift has occurred that has resulted in the imposition of more constraint on judicial decision-making concerning the admission of young people's statements. While the scope of judicial discretion surrounding the admissibility of young offender statements under the $Y C J A$ is not inconsiderable, it is our view that the current drafting of the legislation does significantly curtail the types of factors youth court judges will be able to take into account when considering questions of youth statement admissibility. To trace this legislative evolution we examine the provisions of the current s. 146 of the $Y C J A$, the key section that will govern the admissibility of young people's statements, and compare it to the previous version of the Bill as well as the provisions of s. 56 of the $Y O A$, the key provision currently governing the admissibility of young people's statements. In addition, in order to assess the impact of the new legislation, the case law concerning voluntariness of statements and Charter rights in relation to statements will briefly be analyzed.

This paper fills an important gap in the literature concerning the admissibility of young offender statements. Because the provisions on young people's statements contained within the $Y C J A$ are of relatively recent vintage, there does not exist any academic commentary regarding these sections of the $A c t$, at least as they are presently drafted. Moreover, although there does exist a significant body of work dealing with the the admissibility of young people's statements under the $Y O A,{ }^{8}$ this literature tends to focus on the statutory prerequisites for admitting statements and pays little, if any, heed to the constitutional and common law requirements for youth statement admissibility and the potential interrelationship between the different sources of law that impact upon this area. ${ }^{9}$

\section{LEgiSLATIVE OVERVIEW}

\section{A. COMPaRISON SUMMARY OF KEY STATUTORY RULES}

The following is a chart comparing the provisions of s. 146 of the $Y C J A$, as it is currently drafted, with the previous legislative proposal ${ }^{10}$ and the provisions of s. 56 of the $Y O A$. Brief comment is made on the potential significance of any changes.

* See, for example, J. Bolton et al., "The Young Offenders Act: Principles and Policy - the First Decade in Review" (1993) 38 McGill L.J. 939 at 984-1005; N. Bala, Young Offenders Law (Concord: Irwin Law. 1997) at 105-25; and B.D. Stuart, "The Wonderful World of Section 56" (1985) 9 Prov. Judges J. 13.

" To a certain extent this is understandable given the fact that the statutory preconditions to admissibility of young offender statements under the $Y O A$ are, in many respects, more onerous, as far as police and prosecuting authorities are concerned, than the constitutional and common law prerequisites to statement admissibility.

II The previous version of the YCJA that is referred to is the initial Bill tabled in Parliament. Bill C-68, Youth Criminal Justice Act, 1st Sess., 36th Parl., 1999 (it died on the Order Paper when the session of Parliament ended 18 September 1999). A subsequent version of the YCJA was introduced on October 14, 1999, but it also died on the Order Paper when the Liberal government called an early federal election. See Bill C-3, Youth Criminal Justice Act, 36th Parl., 1999 (it died on the Order Paper when Parliament was dissolved 22 October 2000). The sections governing the admissibility of young people's statements are identically worded in these versions of the YCJA. 
VOL. 39(4) 2002

\begin{tabular}{|c|c|c|c|}
\hline $\begin{array}{l}\text { Current Proposed } \\
\text { Provision }\end{array}$ & $\begin{array}{l}\text { Previous Proposed } \\
\text { Provision }\end{array}$ & Current s. 56 & Comment \\
\hline $\begin{array}{l}\text { s. } 146(1) \text { Subject to this section, } \\
\text { the law relating to the } \\
\text { admissibility of statenents made } \\
\text { by persons accused of } \\
\text { cominitting offences applies in } \\
\text { respect of young persons. }\end{array}$ & Equivalent provision. & Equivalent. & No cliange. \\
\hline $\begin{array}{l}\text { s. 146(2) No oral or written } \\
\text { statement made by a young } \\
\text { person who is less than eighteen } \\
\text { years old, to a peace officer or } \\
\text { to any other person who is, in } \\
\text { law, a person in authority, on } \\
\text { the arrest or detention of the } \\
\text { young person or in } \\
\text { circumstances where the peace } \\
\text { officer or other person has } \\
\text { reasonable grounds for believing } \\
\text { that the young person has } \\
\text { committed an offence is } \\
\text { admissible against the young } \\
\text { person unless } \\
\text { (a) the statement was voluntary; } \\
\text { (b) the person to whotn the } \\
\text { statement was inade has, before } \\
\text { the statement was made, clearly } \\
\text { explained to the young person, } \\
\text { in language appropriate to his or } \\
\text { her age and understanding." } \\
\text { that } \\
\text { (i) the young person is under no } \\
\text { obligation to make a statement. } \\
\text { (ii) any statement made by the } \\
\text { young person may be used as } \\
\text { evidence in proceedings against } \\
\text { hun or her. } \\
\text { (iii) the young person has the } \\
\text { right to consult counsel and a } \\
\text { parent or other person in } \\
\text { accordance witl paragraph (c). } \\
\text { and } \\
\text { (iv) any statement made by the } \\
\text { young person is required to be } \\
\text { inade in the presence of counsel } \\
\text { and any other person consulted } \\
\text { in accordance with paragraph } \\
\text { (c), if any, unless the young } \\
\text { person desires otherwise: } \\
\text { (c) tlie young person lias. before } \\
\text { the statement was made. been } \\
\text { given a reasonable opportunity } \\
\text { to consult }\end{array}$ & Equivalent. & $\begin{array}{l}\text { Does not contain the } \\
\text { proviso that an } \\
\text { "appropriate adult" } \\
\text { selected for } \\
\text { consultation with the } \\
\text { young person excludes } \\
\text { co-accused or those } \\
\text { under investigation in } \\
\text { respect of the same } \\
\text { offence. }\end{array}$ & $\begin{array}{l}\text { Minor change regarding } \\
\text { definition of "appropriate } \\
\text { adult." }\end{array}$ \\
\hline
\end{tabular}

The requirement that the statutory warnings be given in language appropriate to the young person's age and understanding is crucial, especially in light of empirical work suggesting that those young people who do not understand their enhanced procedural rights under the YOA are more likely to sign a written waiver of those rights. See R. Abramovitch, K. Higgins-Biss \& S.R. Biss, "Young person's comprehension of waivers in criminal proceedings" (1993) 35 Can. J. Crim. 309 at 316-318. 


\begin{tabular}{|c|c|c|c|}
\hline $\begin{array}{l}\text { Current Proposed } \\
\text { Provision }\end{array}$ & $\begin{array}{l}\text { Previous Proposed } \\
\text { Provision }\end{array}$ & Current s. 56 & Cominent \\
\hline $\begin{array}{l}\text { (i) with counsel, and } \\
\text { (ii) with a parent or, in the } \\
\text { absence of a parent, all adult } \\
\text { relative or, in the absence of a } \\
\text { parent and an adult relative, any } \\
\text { other appropriate adult chosen } \\
\text { by the young person, as long as } \\
\text { that person is not a co-accused. } \\
\text { or under investigation. in } \\
\text { respect of the same offence; and }\end{array}$ & & & \\
\hline $\begin{array}{l}\text { (d) if the young person consults } \\
\text { a person in accordance with } \\
\text { paragraph (c), the young person } \\
\text { has been given a reasonable } \\
\text { opportunity to make the } \\
\text { statement in the presence of that } \\
\text { person. }\end{array}$ & & & \\
\hline $\begin{array}{l}\text { s. 146(3) The requirements set } \\
\text { out in paragraplis ( } 2 \text { (b) to (d) } \\
\text { do not apply in respect of oral } \\
\text { statements if they are made } \\
\text { spontaneously by the young } \\
\text { person to a peace officer or } \\
\text { other person in authority before } \\
\text { that person has had a reasonable } \\
\text { opportunity to comply with } \\
\text { those requirements. }\end{array}$ & Equivalent. & Equivalent. & $\begin{array}{l}\text { No change - the res } \\
\text { gestue exception continues. }\end{array}$ \\
\hline $\begin{array}{l}\text { s. } 146(4) \text { A young person may } \\
\text { waive the rights under } \\
\text { paragraph }(2)(c) \text { or (d) but any } \\
\text { such waiver } \\
\text { (a) must be recorded on video } \\
\text { tape or audio tape; or } \\
\text { (b) must be in writing and } \\
\text { contain a statement signed by } \\
\text { the young person that lie or she } \\
\text { has been informed of the right } \\
\text { being waived. }\end{array}$ & Equivalent. & $\begin{array}{l}\text { Waiver lias to be in } \\
\text { writing or videotaped. }\end{array}$ & $\begin{array}{l}\text { Only cliange from the } \\
\gamma(O A \text { is that the section as } \\
\text { proposed would expressly } \\
\text { authorize an audiotaped } \\
\text { waiver as well as a written } \\
\text { and videotaped waiver. }\end{array}$ \\
\hline $\begin{array}{l}\text { s. } 146(5) \text { When a waiver of } \\
\text { rights under paragraph }(2)(c) \text { or } \\
\text { (d) is not made in accordance } \\
\text { with subsection (4) owing to a } \\
\text { technical irregularity, the youth } \\
\text { justice court may deternine that } \\
\text { the waiver is valid if it is } \\
\text { satisfied that the young person } \\
\text { was informed of his or her } \\
\text { rights and voluntarily waived } \\
\text { them. }\end{array}$ & $\begin{array}{l}\text { Allows the court to admit } \\
\text { into evidence a statement } \\
\text { obtained even when the } \\
\text { statutory requirements } \\
\text { pertaining to waiver of } \\
\text { enhanced procedural } \\
\text { rights is not complied } \\
\text { with. The only condition } \\
\text { of admissibility is that the } \\
\text { court be satisfied that the } \\
\text { young person was } \\
\text { informed of his or her } \\
\text { rights and waived them. }\end{array}$ & $\begin{array}{l}\text { No provision allowing } \\
\text { the reception into } \\
\text { evidence of statements } \\
\text { inade without } \\
\text { compliance of the } \\
\text { enhanced procedural } \\
\text { protections or the } \\
\text { waiver requirements. }\end{array}$ & $\begin{array}{l}\text { The section as proposed } \\
\text { allows the reception into } \\
\text { evidence of statements } \\
\text { when the young person } \\
\text { waives his or her rights } \\
\text { voluntarily even though } \\
\text { the statutory requirements } \\
\text { for waiver have not been } \\
\text { met if the failure to } \\
\text { comply with the legislative } \\
\text { requirements is due to a } \\
\text { technical irregularity. Bill } \\
\text { C. } 68 \text { allowed for wider } \\
\text { admissibility of statements } \\
\text { obtained in breach of the } \\
\text { statutory requirements for }\end{array}$ \\
\hline
\end{tabular}




\begin{tabular}{|c|c|c|c|}
\hline $\begin{array}{l}\text { Current Proposed } \\
\text { Provision }\end{array}$ & $\begin{array}{c}\text { Previous Proposed } \\
\text { Provision }\end{array}$ & Current s. 56 & Comment \\
\hline & & & $\begin{array}{l}\text { waiver. Such statements } \\
\text { were admissible under Bill } \\
\text { C- } 68 \text { as long as the young } \\
\text { person was informed of } \\
\text { his or lier rights and } \\
\text { waived them, even if the } \\
\text { reason the legislative } \\
\text { requirements for waiver } \\
\text { were not met went beyond } \\
\text { a mere technical } \\
\text { irregularity. }\end{array}$ \\
\hline $\begin{array}{l}\text { s. } 146(6) \text { When there has been a } \\
\text { technical irregularity in } \\
\text { complying with paragraphs } \\
(2)(b) \text { to }(d) \text {, the youth justice } \\
\text { court may admit into evidence a } \\
\text { statement referred to in } \\
\text { subsection (2) if satisfied that } \\
\text { the admission of the statement } \\
\text { would not bring into disrepute } \\
\text { the principle that young persons } \\
\text { are entilled to enhanced } \\
\text { procedural protection to ensure } \\
\text { that they are treated fairly and } \\
\text { their rights are protected. }\end{array}$ & $\begin{array}{l}\text { Seems to be more broadly } \\
\text { cast, permitting } \\
\text { admissibility of } \\
\text { statements where the } \\
\text { court, having regard to all } \\
\text { the circumstances and the } \\
\text { principles and objectives } \\
\text { of the } A c t \text {, determines it } \\
\text { would not bring the } \\
\text { administration of justice } \\
\text { into disrepute. }\end{array}$ & No equivalent. & $\begin{array}{l}\text { This is a significant } \\
\text { alteration. The narrowing } \\
\text { from the prior proposal } \\
\text { results in the following: in } \\
\text { order to admit statements } \\
\text { obtained in breach of the } \\
\text { statutory provision, the } \\
\text { breach inust be a inere } \\
\text { technical irregularity. } \\
\text { The test for exclusion is } \\
\text { now whether admission } \\
\text { brings into disrepute tlie } \\
\text { principle of enhanced } \\
\text { procedural protection, } \\
\text { rather than the more } \\
\text { familiar s. } 24 \text { ('harter } \\
\text { formulation. }\end{array}$ \\
\hline $\begin{array}{l}\text { s. } 146(7) \text { A youth justice court } \\
\text { may rule inadinissible in any } \\
\text { proceedings under this Act a } \\
\text { statement made by the young } \\
\text { person in respect of whom the } \\
\text { proceedings are taken if the } \\
\text { young person satisfies the judge } \\
\text { that the statement was inade } \\
\text { under duress imposed by any } \\
\text { person who is not, in law. a } \\
\text { person in authority. }\end{array}$ & Equivalent. & Equivalent. & $\begin{array}{l}\text { Key issues remain defining } \\
\text { a person in authority and } \\
\text { duress. }\end{array}$ \\
\hline $\begin{array}{l}\text { s. } 146(8) \text { A youth justice court } \\
\text { may in any proceedings under } \\
\text { this Act rule admissible any } \\
\text { statement or waiver by a young } \\
\text { person if, at the time of the } \\
\text { making of the statement or } \\
\text { waiver. } \\
\text { (a) the young person lield } \\
\text { himself or herself to be eighteen } \\
\text { years old or older; } \\
\text { (b) the person to whoun the } \\
\text { statement or waiver was made } \\
\text { conducled reasonable inquiries } \\
\text { as to the age of the young } \\
\text { person and had reasonable } \\
\text { grounds for believing that the } \\
\text { young person was eigliteen } \\
\text { years old or older; and }\end{array}$ & Equivalent. & Equivalent. & No change. \\
\hline
\end{tabular}




\begin{tabular}{|l|l|l|l|}
\hline \multicolumn{1}{|c|}{$\begin{array}{c}\text { Current Proposed } \\
\text { Provision }\end{array}$} & $\begin{array}{c}\text { Previous Proposed } \\
\text { Provision }\end{array}$ & Current s. 56 & Comment \\
\hline $\begin{array}{l}\text { (c) in all other circumstances } \\
\text { the statement or waiver would } \\
\text { otherwise be admissible. }\end{array}$ & & $\begin{array}{l}\text { Instead of using the } \\
\text { phrase "person } \\
\text { consulted." the } Y(\text { )A } \\
\text { provision utilizes the } \\
\text { plurase "adult } \\
\text { consulted." }\end{array}$ & No substantial cliange. \\
\hline $\begin{array}{l}\text { s. 146(9) For the purpose of this } \\
\text { section. a person consulted } \\
\text { under paragraph (2)(c) is. in the } \\
\text { absence of evidence to the } \\
\text { contrary, deemed not to be a } \\
\text { person in authority. }\end{array}$ & Equivalent. & & \\
\hline
\end{tabular}

As should be evident from the chart, a number of rules have not been changed by the proposed s. 146. First, to be admissible, any statement given by the young person to a person in authority must be voluntary. ${ }^{12}$ Second, young people enjoy enhanced procedural protections, including the right to be fully cautioned and to have a third person present when making a statement. Third, spontaneous statements are admissible if the authorities have not had a reasonable opportunity to comply with the enhanced procedural protections for young offender statement gathering. Fourth, any waiver of a youth's enhanced procedural protections regarding statements must be fully recorded. Fifth, a statement made under duress may be inadmissible, notwithstanding that it is made to someone who is not a person in authority. The sixth and final rule that continues unaltered under the new juvenile justice legislative regime is that the more stringent caution and waiver requirements for youths would not apply if the young person represents himself/herself as being over eighteen years of age and this representation is objectively believable.

Yet the new legislation does usher in some significant changes. For instance, although non-compliance with the caution and third party presence rule under s. 56 of the YOA would result in exclusion of the statement, judicial discretion is explicitly recognized in the new legislation and permits admission of the resulting statement in limited circumstances. Moreover, whereas non-compliance with the waiver requirements regarding young offender statements would have resulted in exclusion of the statement under s. 56, judicial discretion is allowed by the $Y C J A$ to permit admission of the resulting statement in limited circumstances.

12. The classic formulation of the voluntariness test for confessions is contained in $R$. v. Ibrahim. [19/4] A.C. 599 at 609 (P.C.) and is stated as follows:

It has long been established as a positive rule of English criminal law, that no statement by an accused is admissible in evidence against him unless it is shewn by the prosecution to have been a voluntary statement, in the sense that it has not been obtained from him by fear of prejudice or hope of advantage exercised or held out by a person in authority.

The contemporary confessions rule goes beyond considerations of threats or promises made to the accused and includes such factors as whether the confession was elicited under oppressive circumstances, whether the accused had an operating mind when he/she confessed, and whether the police used trickery in order to obtain the confession. For a detailed discussion of the modern common law confessions rule, see $R$. v. Oickle, [2000] 2 S.C.R. 3 at 31-45 [hereinafter Oickle]. It should be noted that the confession rule applies to all oral or written statements made by an accused to a person in authority proffered by the Crown in criminal or quasi-criminal proceedings. 


\section{Discussion OF RULES OF ADMISSIBILITY}

\section{A. SOURCES OF RULES GOVERNING ADMISSIBILITY}

It is important to note the different sources of law applicable to young offender statements because defence counsel may increasingly find that they are unable to rely on the failure of the state to comply with statutory prerequisites in order to exclude inculpatory youth statements. There are actually three bodies of law that are applicable to young offender statements: the common law rules of voluntariness, ${ }^{13}$ the provisions of the Charter (specifically ss. 7, 9, and 10), and the statutory rules governing young offender statements. It would be fair to say, as the Standing Committee observed, that the Supreme Court of Canada requires strict compliance with s. 56 of the YOA. This makes resort to common law and Charter rules less of an imperative in youth court today. However, to the extent that the new proposed provisions are intended to ameliorate against strict compliance with the statutory provisions, defence counsel may fall back onto common law and Charter principles to achieve rulings of inadmissibility.

The interrelationship of the three sources of rules is complex with different burdens of proof, depending on the rule being relied upon. Given the interrelationship of the rules (discussed more fully below) the provisions of s. 146 of the YCJA may make admissibility voir dires complex and potentially confusing. The following brief chart illustrates the rules that may potentially come into play in a voir dire:

\begin{tabular}{|l|l|l|}
\hline \multicolumn{1}{|c|}{ Rule } & \multicolumn{1}{|c|}{ YCJA Provison } & \multicolumn{1}{|c|}{ Burden of Proof } \\
\hline Voluntariness. & s. $146(2)(\mathrm{a})$ & $\begin{array}{l}\text { The evidentiary and legal burden (beyond a } \\
\text { reasonable doubt) are on the Crown. }\end{array}$ \\
\hline Enhanced procedural protection. & s. 146(2)(b) & $\begin{array}{l}\text { The evidentiary and legal burden are on the } \\
\text { Crown. }\end{array}$ \\
\hline Res gestue exception. & s. 146(3) & $\begin{array}{l}\text { The assertion that a statement is res gesfue would } \\
\text { impose an evidentiary and legal burden (balance of } \\
\text { probabilities) on the proponent - normally the } \\
\text { Crown. }\end{array}$ \\
\hline Waiver of right to consult. & s. 146(4) & $\begin{array}{l}\text { The evidentiary and legal burden are on the } \\
\text { Crown." }\end{array}$ \\
\hline
\end{tabular}

13 Specifically preserved by s. $146(2)(a)$ of the $Y C J A$.

is See R. v. J.(J.T.), [1990] 2 S.C.R. 755 [hereinafter J.(J.T.)].

is Normally the onus is on the party seeking to rely upon an exception. See, for example, the approach of the Court in dealing with exceptions to the hearsay rule in $R$. v. Meaney (1996), 145 Nfld. \& P.E.I.R. 305 (C.A.), leave to appeal to S.C.C. refused [1996] S.C.C.A. No. 591, online: QL (SCCA) (1997), 151 Nfld. \& P.E.I.R. 90; R. v. B.(K.G.), [1993] I S.C.R. 740; and R. v. U.(F.J.), [1995] 3 S.C.R. 764. For an example in which the court applied the concept that the onus is on the party seeking to rely upon the res gesıae exception under s. 56(3) of the YOA, see R. v. M.L., [1987] R.J.Q. 709 (Youth Ct.).

It. In $R$. v. Hebert, [1990] 2 S.C.R. 151 the language used regarding waiver under the Charter is "establishes," indicating the Crown would bear the evidentiary and legal burden on this issue. $R$. $v$. Prosper, [1994] 3 S.C.R. 236, emphatically establishes that the burden of establishing waiver of Charter rights is on the Crown. The cases decided under s. 56(4) of the YOA, the provision that deals 


\begin{tabular}{|c|c|c|}
\hline Rule & YCJA Provison & Burden of Proof \\
\hline $\begin{array}{l}\text { Waiver notwithstanding non-compliance } \\
\text { with s. } 146(4) \text {. }\end{array}$ & s. $146(5)$ & $\begin{array}{l}\text { The burden should be the same as immediately } \\
\text { above. }{ }^{17}\end{array}$ \\
\hline $\begin{array}{l}\text { Adtnission of statements } \\
\text { notwithstanding non-compliance with } \\
\text { the enhanced procedural protection } \\
\text { provisions. }\end{array}$ & s. $146(6)$ & $\begin{array}{l}\text { The requirement of "lechnical irregularity" would } \\
\text { seem to place the evidentiary and legal burden on the } \\
\text { Crown." } \\
\text { The wording of (6) is that the court must be satisfied } \\
\text { that admission of the statement would not bring the } \\
\text { principle of enhanced protection into disrepute. This } \\
\text { wording is opposite to the wording of s. } 24(2) \text { of the } \\
\text { ('hurter, whiclt requires the evidence to be excluded } \\
\text { if it is established that the administration of justice } \\
\text { would be brought into disrepute. The change is more } \\
\text { than one of nuance - it would seem that (6) places } \\
\text { the evidentiary and legal burden on the Crown. }\end{array}$ \\
\hline $\begin{array}{l}\text { Statements made to a person not in } \\
\text { authority and under duress. }\end{array}$ & ss. $146(7)$ and $(9)$ & $\begin{array}{l}\text { There is an evidentiary burden on the accused to } \\
\text { raise the issue of whether the person to whom the } \\
\text { statement is made is a person in authority. There is } \\
\text { probably a similar burden on the accused with } \\
\text { respect to the issue of duress as well." The burden } \\
\text { on the Crown should be to rebut or negative duress } \\
\text { beyond a reasonable doubt. The issue of duress } \\
\text { would certainly relate to the truthfulness of the } \\
\text { statement as an aspect of voluntariness." }\end{array}$ \\
\hline $\begin{array}{l}\text { Misrepresentation of age vitiating non- } \\
\text { compliance with enlianced procedural } \\
\text { protections. }\end{array}$ & s. $146(8)$ & $\begin{array}{l}\text { The evidentiary and legal burden rests with the } \\
\text { Crown. }\end{array}$ \\
\hline (harter breach. & & $\begin{array}{l}\text { The evidentiary and legal burden (balance of } \\
\text { probabilities) to establish the (harter breach is on } \\
\text { the young person. } \\
\text { The burden under s. } 24(2) \text { is also on the accused, but } \\
\text { where the evidence is conscriptive, it would seem } \\
\text { that presumptively it affects trial fairness and thus } \\
\text { there is a pragmatic shift to the Crown." }\end{array}$ \\
\hline
\end{tabular}

with waiver of the right to consult counsel and other appropriate aduits, also establish that the evidentiary and legal burden concerning waiver rests with the Crown. See, for example, R. v. J.C.S. (7 June 1993), T.C. 92-00005, Y.O.S. 94-022 (Terr. Ct. Y.), Stuart T.C.J. and R. v. B.S.M. (1995), 100 Man. R. (2d) 151 (C.A.).

17 This result would certainly seem to flow from the analysis of the Supreme Court in J. (J.T.), supra note 14. See also R. v. M.A.M. (1986), 32 C.C.C. (3d) 566 (B.C.C.A.) and R. v. W.(B.C.) (1986), 40 Man. R. (2d) 216 (C.A.) [hereinafter W.(B.C.)].

ix In IWA v. Consolidated-Bathurst Packaging Ltd., [1990] I S.C.R. 282, the Court held that where a party relies upon a technical irregularity the onus in on that party to establish a mere technical irregularity.

1. See R. v. W.K.R. (1985), 14 W.C.B. 372 (Ont. Prov. Ct.), online: QL (OJ). R. v. Hodgson, [1998] 2 S.C.R. 449 [hereinafter Hodgson] clearly places the evidentiary burden on adult accused and the ultimate burden on the Crown vis-à-vis whether someone is a person in authority.

20 In R. v. Ruzic, [2001] I S.C.R. 687 [hereinafter Ruzic], LeBel J. dealt with the common law defence of duress, and specifically rejected the Crown's submission that the legal burden should be on the accused. Rather, the burden is on the Crown - beyond a reasonable doubt.

21 See R. v. Burlingham, [1995] 2 S.C.R. 206 and R. v. Stillman, [1997] I S.C.R. 607 


\section{B. VOLUNTARINESS}

It is sometimes forgotten that, even before the enactment of the YOA, a notion of enhanced procedural protection was part of the common law with respect to the admissibility of young offender statements. In $R$. v. Yensen, ${ }^{22}$ McRuer C.J.H.C. indicated that a parent should be present if a child is to be questioned with a view to soliciting a confession. ${ }^{23}$ Additionally, if there is a purported waiver, the officer must be in a position to demonstrate that the child understood the caution as "a result of careful explanation" and that "the consequences that may flow from making the statement" should be pointed out to the child. ${ }^{24}$ This concept of enhanced procedural protection was adopted in a number of subsequent cases. ${ }^{25}$ While normally a caution was not absolutely necessary to establish voluntariness, ${ }^{26}$ cautions were viewed as being of particular importance in cases involving young offenders. In $R$. v. $A .,{ }^{27}$ Shannon J. reviewed the decisions and concluded that, because juveniles are particularly vulnerable to police questioning, a statement by a youth should be carefully scrutinized with regard to a number of factors. Although the Court decided it is not a rule of law that a statement taken from a juvenile is inadmissible if taken without a parent or other relative being present, there are several factors that determine whether the statement given was voluntary. The factors include: whether a relative, preferably of the same sex, accompanied the accused; whether the accused was given the choice of deciding whether he/she wished the relative to be present; how long the accused was kept waiting; whether any caution given was explained to the accused; whether the accused, if he/she was over fourteen years old, was told he/she could be tried in adult court for the offence; and whether the accused, if he/she was detained, was properly detained in a place kept only for the detention of children.

Subsequent cases confirmed the seriousness with which the courts regarded these guidelines. ${ }^{28}$ In $R .(A)(R e)^{29}$ Lilles Y.C.J., after referring to the cases on voluntariness and young offenders, articulated further reasons for demanding a stringent onus on the Crown to establish voluntariness, including: (1) the reduced capacity of young people to understand rights, (2) the reduced capacity of youths to protect themselves in the adult world, and (3) the increased disposition of young people to answer all questions posed by authorities. ${ }^{30}$

R. v. Yensen. [1961] O.R. 703 (H.C.J.) [hereinafter Yensen].

Some commentators view this aspect of Yensen as constituting merely ill-thought obiter dicta. Sec, for example, W. Fox, "Confessions by Juveniles" (1962-63) 5 Crim. L.Q. 459. Yensen, supra note 22 at $710-11$.

See, for example, $R$. v. M. (1975), 7 O.R. (2d) 490 (H.C.J.) and R. v. N.C., [1978] O.J. No. 899 (Prov. Ct.), online: QL (OJ).

Boudreau v. The King, [1949] S.C.R. 262.

(1975). 23 C.C.C. (2d) 537 (Alta. S.C.(T.D.)).

See, for example. R. v. K.S., [1982] O.J. No. 383 (Prov. Ct.), online: QL (YJ) and R. v. A.B., [1981]

O.J. No. 960 (Prov. Ct.), online: QL (OJ).

[1990] Y.J. No. 97 (Youth Ct.), online: QL (YJ).

lbid. at paras. 9-1I. 
Additionally, the common law with respect to voluntariness in general continues to evolve, moving toward a higher standard of evidence to ensure that proper procedures have been followed. In Oickle the Supreme Court gave tacit approval to the practice of taping interrogations. While not stated as a requirement, as the Manitoba Court of Appeal noted, the law "greatly favours the growing practice of recording police interrogations, preferably by videotape." 31 Indeed, the Court held that the absence of contemporaneous recording should be taken into account in the assessment of the credibility of police officers. ${ }^{32}$ These sentiments were recently echoed and amplified by the Ontario Court of Appeal's statement that it is difficult to see how the Crown could discharge its onus of proving voluntariness where proper recording procedures are not followed. ${ }^{33}$

\section{The INTERPLAY OF VOLUNTARINESS, SECTION 56 OF THE YOA, SECTION 146 OF THE YCJA, AND THE CHARTER}

The potentially greater scope of the voluntariness rule as it affects young persons was recognized by the Supreme Court in $R$. v. I.(L.R.),$^{34}$ which dealt with the question of whether s. 56 of the YOA required that a warning be given concerning the possibility of a case being raised to adult court. The Supreme Court held that such a warning was not a requirement of s. 56(2), but it was an aspect of voluntariness and an aspect of determining whether there had been a waiver of counsel pursuant to s. 10(b) of the Charter. The interplay among the common law rules, the Charter, and s. 56 of the YOA was important in this case. For there to be a valid waiver, s. 56 would have to be construed in conformity with s. 10 of the Charter, necessitating a full appreciation of potential consequences of waiving the right to counsel.

However, navigating between the common law rules, constitutional rights, and statutory provisions influencing the admissibility of young offender statements can be difficult because of the disparate burdens of proof, scope of protection, and breach consequences pertaining to each of the sources of law governing juvenile statements. Non-compliance with the rigours of s. 56 means a statement will be deemed inadmissible. ${ }^{35}$ And in this feature, s. 56 is like the common law voluntariness rule, which equally dictates exclusion if a statement is found to be non-voluntary, but s. 56 is unlike the Charter, which requires a balancing test to be applied before a statement obtained in breach of the Charter is excluded. ${ }^{36}$ Common law rules pertaining to youth statements contain "enhanced procedural protections," which are broader in some aspects than either s. 56 of the YOA or the Charter, and breach of these common law rules mandates exclusion of the statements. ${ }^{37}$ The Supreme Court also requires that s. 56 be read consistently with the Charter.

R. v. Bunn (2001), 153 Man. R. (2d) 264 at para. 13, online: QL (MJ) citing lacobucci J. in Oickle. lbid. at para. 17.

R. v. Moore-McFarlane, [2001] O.J. No. 4646 at para. 67, online: QL (OJ).

[1993] 4 S.C.R. 504.

Ibid. See also J.(J.T.), supra note 14.

See discussion in Oickle, supra note 12 at 25.

The key differences between the "voluntary" rule and the Charter rules are fully explored in Oickle (ibid.). 
Adding to this already complex and confusing picture are the reforms of the $Y C J A$, most notably the introduction of judicial discretion into the admissibility rules. What may occur under the new juvenile justice legislative regime is that defence counsel will argue that s. 146 of the $Y C J A$ must also be read in compliance with the Charter. Moreover, defence counsel will undoubtedly argue for the exclusion of young offender statements under the common law rules. As a result, some voir dires may become a mixture of all three sets of rules.

\section{INTERRELATIONSHIP OF VOLUNTARINESS AND Statements Made to a Person not In authority}

Section 146(7) provides that a statement made to a person not in authority may nevertheless be inadmissible if the young person satisfies the judge that the statement was made under duress. This provision serves as a significant safeguard for young people who make statements to individuals who are not persons in authority. The first key question concerns whether or not the person to whom the statement is made constitutes a "person in authority," because if so, the admissibility of the young person's statement will be governed by ss. 146(2)-(6). There is nothing in the terms of the YCJA that would alter the meaning of the phrase "person in authority" as interpreted by the Supreme Court in $R$. v. Hodgson $^{38}$ and $R$. v. Wells, ${ }^{39}$ which clearly place an evidentiary onus on the accused to raise this issue and which establish an objective/subjective test for determining whether an individual is a person in authority. In Hodgson, the Court articulates the following principles regarding persons in authority:

Though no absolute definition of "person in authority" is necessary or desirable, it typically refers to those formally engaged in the arrest, detention, examination or prosecution of the accused. Thus, it would apply to persons such as police officers and prison officials or guards.... Those persons whom the accused reasonably believes are acting on behalf of the police or prosecuting authorities and could therefore influence or control the proceedings against him or her may also be persons in authority. That question will have to be determined on case by case basis.... The issue as to who is a person in authority must be resolved by considering it subjectively from the viewpoint of the accused. There must, however, be a reasonable basis for the accused's belief that the person hearing the statement was a person in authority. ${ }^{40}$

In youth courts, as in adult courts, the issue is approached on a case-by-case basis. It becomes problematic when the individual asserted to be a person in authority is also the young person's parent ${ }^{41}$ or guardian, ${ }^{42}$ and is the person consulted. However, the YCJA does not purport to change the rules concerning the meaning of a person in authority, and courts will continue struggling to determine whether, in the circumstances of a case, a parent or guardian may be such a person.

Supra note 19.

[1998] 2 S.C.R. 517 [hercinafter Wells].

Supra note 19 at 482.

See, for example, $R$ v. A.B. (1986), 26 C.C.C. (3d) 17 (Ont. C.A.).

See for example, $R$. v. K.S., supra note 28 , a case involving group home "parents." 
If an adult accused gives a statement to a person who is not a person in authority, such a statement is admissible against him/her, but measures exist to ensure the fairness of the trial. The Criminal Code does not contain a comparable provision to s. 146(7) of the $Y C J A$. As a result, there is no specific statutory authority to exclude statements made under duress to persons who are not persons in authority. In addition, in Hodgson and Wells the Supreme Court eschewed a view of inadmissibility of adult statements given to someone who is not a person in authority even in situations of major violence. However, the Court held that if a receiver of a statement was not a person in authority but the statement was obtained by reprehensible coercive tactics such as violence or credible threats of violence, then a cautioning direction should be given to the jury. Specifically, the jury should be instructed that if they conclude that the statement was obtained by coercion, they should be cautious about accepting it and attaching much weight to it. ${ }^{43}$

Although the application of Hodgson and Wells in the young offender context would provide youths some protection regarding their statements to individuals who are not persons in authority, the $Y C J A$ 's recognition of the power to exclude such statements is an acknowledgment by Parliament of the higher degree of vulnerability of many young people compared to adults. Therefore, counsel for a youth may argue that an individual is a person in authority and that the procedural requirements of ss. 146(2) and (4) as well as the common law preconditions to admissibility must be met before a statement given to that person can be admitted into evidence. Alternatively, the defence may argue that, although in the circumstances of the case the individual to whom a statement was given was not a person in authority, the young person's statement should not be given much weight because it was obtained by coercive means. If the young person can establish that the statement, although given to a person who is not a person in authority, was made under duress, the statement may be excluded pursuant to s. 146(7) of the YCJA.

But what is an appropriate definition for duress within the meaning of s. 146(7)? Duress as a defence pursuant to s. 17 of the Criminal Code, even as modified by the Supreme Court in Ruzic, would not seem to be an appropriate test, for it is dealing with a situation in which a person is raising a defence to having committed a criminal act pursuant to the duress. Duress in a civil context ${ }^{44}$ may be argued as being more apt since it is inclusive of undue influence, fraud, negligent misrepresentation, and deceit. ${ }^{45}$ The civil definition stresses the impact on the exercise of proper judgment, ${ }^{46}$ while the criminal test emphasizes the loss of free will. The definition of duress may be the focus of some debate, though it would seem that the emphasis on exercise of proper judgment is particularly pertinent to young persons. The counter-argument would be that using the loss of free will test would underscore that the statement so lacks in probative value that it should be excluded. ${ }^{47}$

Hodgson, supra note 19 at 483.

See Martel Building v. Canada, [2000] 2 S.C.R. 860.

Ibid. at para. 71.

See, for example, the forced resignation case of Regina Police Assn. v. Regina (City) Board of Police Commissioners, [2000] l S.C.R. 360.

Support for the "loss of free will" definition of duress, at least as that term is used in s. 56(5) of the YOA, can be found in J. Hanson, "Youth Confessions: Section 56 of the Young Offenders Act" (1987) 6 Can. J. Fam. L. 191 at 209 and R. v. C.C. (1984), 15 W.C.B. 71 (Ont. Prov. Ct.). 


\section{Judicial Discretion to Admit Statements Pursuant to the $Y C J A$}

While the proposed s. 146 of the $Y C J A$ requires a waiver of the enhanced procedural rights given to young people under the $A c t$ to be in writing and signed, or video or audio taped, non-compliance will not be fatal pursuant to s. 146(5) if it is due to technical irregularity and if the youth court judge is satisfied that there was a voluntary waiver. The key issue will be what constitutes a "technical irregularity." There is nothing in the wording of s. 146(5) that suggests an oral waiver would suffice. In other words, the nonrecording of a waiver would likely not constitute a technical irregularity. Support for this view can be found in the judicial statements, recounted earlier in this paper, that recording interrogations is desirable, if not an actual precondition to statement admissibility.

Existing jurisprudence also suggests that s. 146(5) will be given a narrow interpretation. Although the phrase "technical irregularity" does not appear in the YOA and has not been considered by the Supreme Court within the context of other criminal legislation, the phrase has been interpreted by the high court in construing labour legislation and by other courts when dealing with criminal matters. The Supreme Court ruled that the failure to comply with exact provisions of a collective agreement did not constitute a mere "technical irregularity" within the meaning of Ontario's labour legislation. ${ }^{48}$ The Nova Scotia Court of Appeal and the New Brunswick Court of Queen's Bench have determined that usage of wrong forms or omission of particular words in the forms used to create arrest warrants and informations, that do not result in the exclusion of anything of substance, constitute mere technical irregularities. ${ }^{49}$ Thus if the required warnings were given and explained but the waiver form itself did not have precise enough language, such a situation might constitute a technical irregularity within the meaning of s. 146(5).

Nevertheless, this type of scenario is not the only one in which s. 146(5) might save an otherwise deficient waiver. It is not far fetched to imagine situations in which legitimate attempts have been made to use video or audio recording but the device fails.

A more difficult situation might arise if an officer sought to question a suspect at a scene without having the waiver forms or recording devices at hand. It seems likely that an officer in such a circumstance who proceeds to question the suspect would be making a choice not to delay the questioning until compliance can be assured, which should take the situation outside the realm of "technical irregularity."

Statements made in the context of "street questioning" would be better considered under s. $146(3)$ of the $Y C J A$, which, like its identical counterpart s. 56(3) of the $Y O A$, requires that before a statement to a person in authority can be admitted into evidence without complying with the enhanced legislative procedural protections, the statement must arise entirely from natural impulse without any external stimulus or constraint. ${ }^{50}$

General Truck Drivers Union, Local 939 v. Hoar Transport, [1969] S.C.R. 634.

Pigeau v. Crowell (1990), 96 N.S.R. (2d) 412 (C.A.) and Re Lanteigne (1981), 43 N.B.R. (2d) 440 (Q.B.). These courts ruled that such irregularities do not render the affected warrants and informations nullities.

See, for example, R. v. W.(J.) (1996), 30 O.R. (3d) 342 (C.A.). 
The external stimulus need not be a question or direction from a person in authority but may result from the mere presence of a person in authority given the greater likelihood of young persons to be compliant with persons in authority. ${ }^{51}$ Absent some exigent circumstances or where compliance is not reasonably achievable, a statement made in the presence of a person in authority should not be considered spontaneous. ${ }^{52}$

Equally, the age or "street smarts" of a suspect should not be considered in assessing whether a waiver of enhanced procedural rights was not made due to a "technical irregularity." The Supreme Court of Canada held in J. (J.T.) that the YOA's statutory compliance requirements apply to all young people. As Cory J. for the majority stated:

By its enactment of s. 56, Parliament has recognized the problems and difficulties that beset young people when confronted with authority. It may seem unnecessary and frustrating to the police and to society that a worldly wise, smug 17-year-old with apparent anti-social tendencies should receive the benefit of this section. Yet it must be remembered that the section is to protect all young people of 17 years or less. A young person is usually far more easily impressed and influenced by authoritarian figures. No matter what the bravado and braggadocio that young people may display, it is unlikely that they will appreciate their legal rights in a general sense or the consequences of oral statements made to persons in authority; certainly they would not be able to appreciate the nature of their rights to the same extent as would most adults. Teenagers may also be more susceptible to subtle threats arising from their surroundings and the presence of persons in authority. A young person may be more inclined to make a statement, even though it is false, in order to please an authoritarian figure. It was no doubt in this recognition of the additional pressures and problems faced by young people that led Parliament to enact this code of procedure. ${ }^{53}$

Accordingly, the provisions of the YOA were held not to be applied differentially depending upon the young person's age, maturity, or length of record:

Section 56 exists to protect all young people, particularly the shy and the frightened, the nervous and the naive. Yet justice demands that the law be applied uniformly in all cases. ${ }^{54}$

These policy and equity principles are substantial and substantive in nature. Consequently, the age and "street smarts" of youths should not be taken into account in assessing whether non-compliance with the waiver requirements constitutes a mere technical irregularity.

Section 146(6) of the $Y C J A$ permits a statement to be admitted notwithstanding a breach of s. 146(2), provided the non-compliance is a technical irregularity and if the court is satisfied that admission would not bring into disrepute the principle that young persons are entitled to enhanced procedural protection. Although there are significant barriers to successfully invoking s. 146(6), this provision does encompass certain types of situations that could arise. For instance, it is possible that the police may assume that an older male adult who arrives at the police station shortly after a young person is

Ibid.

W. (B.C.), supra note 17.

Supra note 14 at $766-67$ [emphasis added].

Ibid. at 767. 
arrested is the father or another adult relative of the young person. If the adult is the boyfriend of the accused's mother and the police comply with all of the rest of the requirements of s. 146 but take a statement from the young person after he consults with the adult person, it could be concluded that the statement was taken in breach of $\mathrm{s}$. 146(2)(c)(ii). This subsection requires that, before any statement is taken, the young person be given a reasonable opportunity to consult with a parent or, in the absence of a parent, an adult relative, or in the absence of a parent and an adult relative, another appropriate person chosen by the young person. In the example above, the adult consulted was neither a parent nor an adult relative, and it is arguable whether the young person chose the adult or was forced to choose the adult because he was the one who arrived at the police station. The argument that the accused did not actually choose the adult as a consultative source would be buttressed if, upon arrival of this adult, the police did not afford the young person an opportunity to call anyone else except legal counsel.

Whether this breach of s. 146(2)(c)(ii) is a "technical irregularity" would depend upon whether the substance of the legislative warnings and requirements were adhered to by law enforcement officials. In the absence of any indication that the young person did not actually consult or did not wish to consult with the adult person, it is likely that a court would deem the breach to be a mere "technical irregularity." Moreover, if the adult is considered by the accused young person to be sufficiently similar to a parent for consultative purposes, it is likely that a court will rule that admission of the statement would not bring into disrepute the principle that young persons are entitled to enhanced procedural protection because the adult will have served as an effective substitute for the parent. However, if the young person does not regard the adult as a parent for consultative purposes, i.e., the adult is simply an acquaintance of one of the parents and there is no emotional tie to the accused, then the principle of enhanced procedural protection has been infringed, and the statement will likely be ruled inadmissible. Such an adult will probably not be perceived as being as solicitous of the young person's rights and/or interests as a consulted parent, adult relative or other appropriate adult actually chosen by the young person.

\section{Conclusion}

When the $Y C J A$ was first introduced, many of its provisions were very "law and order" oriented. It has been suggested that a number of the amendments to the $Y C J A$ were tabled so that Ottawa could achieve a compromise position between the law enforcement efficiency concerns of provinces like Alberta and Ontario and the concern of Quebec regarding the special needs of youths. ${ }^{5 s}$ Indeed it is plausible that the evolution of the sections of the $Y C J A$ governing young offender statement admissibility is an example of this attempt at compromise.

Despite the amendments to the $Y C J A$, there continues to be overt hostility towards the proposed legislation in Quebec, especially among members of the provincial government. Recently Quebec's Attorney General, Paul Begin, stated his government's intention to refer the legislation to the Quebec Court of Appeal in order to seek that Court's opinion 
as to whether the $Y C J A$ contravenes international children's rights conventions and domestic constitutional law. ${ }^{56}$ Even if the court dismisses arguments challenging the legality of the legislation, the federal government may decide that the political cost of proclaiming the $Y C J A$ in force is too great.

Thus the fate of the $Y C J A$ is still very much in doubt. Although the Bill has received Royal Assent, it is unclear whether the new Federal Minister of Justice hailing from Quebec, Martin Cauchon, will be eager to have this legislation proclaimed in force given the strong opposition to the $Y C J A$ emanating from his home province. ${ }^{57}$

What is clear is that should this legislation be proclaimed in force, the days of defence counsel relying solely upon statutory non-compliance in order to ensure young offender statement inadmissibility are over. As a result, defence counsel need to become reacquainted with the common law rules concerning young offender statements and may need to increasingly challenge the admissibility of young people's statements by bringing Charter applications in youth court.

Nevertheless, the $Y C J A$ should not be seen as an invitation to law enforcement officials to ignore the statutory substantive and procedural safeguards regarding the obtaining of youth statements. The scope of judicial discretion to admit statements obtained in contravention of the legislative provisions is far from absolute. Indeed, it is suggested that this judicial discretion is quite circumscribed.

The initial months and years under the new juvenile justice legislative regime will be a period of great uncertainty as judges attempt to decipher the scope and meaning of various portions of the $Y C J A$. Undoubtedly the judiciary will draw upon much of the jurisprudence decided under the $Y O A$ to the extent that there remain similarities between the two statutes. Yet, in many areas, such as young offender statement admissibility, significant changes have been made. It is incumbent on members of the legal academy and Bar to provide assistance to judges who face the daunting task of breathing life into the new legislation. Hopefully, this article will serve to aid those who must make the oftentimes pivotal decision of whether or not a young person's statement constitutes admissible evidence against him/her. We leave to others the considerable and necessary task of shedding light upon the $Y C J A$ 's other significant reforms to Canada's youth justice system. 